\title{
THE DEVELOPMENT OF THE PROTHALLIUM OF CAMPTOSORUS RHIZOPHYLLUS
}

\author{
F. L. P I C K E T T
}

\section{(WITH PLATES XII AND XIII AND EIGHT TEXT FIGURES)}

In this region the spores of Camptosorus rhizophyllus mature from June to October. The long axis measures $18-24 \mu$, and the shorter I $2-20 \mu$. They contain a few small oil globules, but are destitute of chlorophyll. The nucleus is inconspicuous in the living spore. The perinium is thick, dark, and shows many sharp, irregular ridges with areas of unequal thickness intervening (figs. 47-55). The exospore is seen with difficulty, if at all, as the perinium is very rarely pushed off when the spore germinates.

The spores germinate slowly. The greater part of the writer's material was taken from fronds collected October 26, I9 2 , and kept between sheets of filter paper in a book in the laboratory. On November 22 the sporangia, after being scraped from the fronds, and crushed lightly to free the spores, were sown on well sterilized soil in clay saucers. The saucers of soil were protected from currents of air by bell-jars supported on small blocks of wood to allow proper ventilation, and were kept moist in a well lighted greenhouse at an average temperature a little above $70^{\circ} \mathrm{F}$. The first sign of green was noted with a magnifier on December I 7 . On February 4, I9I3, abundant antheridia were found on the larger prothallia, and one week later a few archegonia were found. On March 22 many old antheridia and archegonia could be found on the large prothallia. Other spores collected October 26, I9I2, were sown December 23, and kept under the same conditions as the above, but out of direct sunlight. In these cultures the first sign of green was noted January 30, I9I3. Other spores sown January 3 and kept in the light, where on days of bright sunshine the temperature reached $80^{\circ} \mathrm{F}$. at midday, showed the first sign of green on January 30 . In all these instances the prothallia were composed of 3-Io cells before their color was noted on the soil. Spores sown on boiled tap water, and kept under the same conditions Botanical Gazette, vol. 57] 
as the above mentioned cultures, showed the beginning of germination in ro-I4 days. While spores collected in October germinated best before the first of February, a considerable percentage germinated as late as the last of March, having been kept in the dry air of the laboratory in the meantime. Spores collected from the usual habitat in March show. a higher percentage of germination than those collected earlier and kept in the laboratory. Only a few mature; unopened sporangia may be found in the field as late as March, so but few spores can be secured at that time.

All the spores sown at one time and under the same conditions do not germinate and develop uniformly into prothallia. A small bit of soil, bearing prothallia, taken from any one of the cultures mentioned above, would show, up to the first of May, widely different stages of prothallial growth. Many times the writer has found on the same bit of soil the intermediate stages from prothallia composed of two or three cells to mature plants $2-3 \mathrm{~mm}$. wide, and bearing antheridia and archegonia. That some of the small prothallia were dwarf male plants is beyond doubt, because of the presence of antheridia. But that some of the spores were late in germination is clearly indicated by the constant recurrence of these gradations in development accompanied by a continual increase in the number of mature specimens. The plants from which the photographs reproduced in pl. XIII were made were taken at one time from the same portion of one culture, and had exactly the same conditions for germination and growth.

\section{Germination of the spore}

When the spores are placed under the proper conditions for germination, they absorb water and increase in diameter from onefourth to one-half. The swelling is followed by a rupture of the perinium and the exposure of the spore contents. The writer has been unable as yet to determine whether or not there are two distinct walls within the perinium. If present, they are quite transparent. Through the opening in the perinium may be seen the oil globules, sometimes an inconspicuous nucleus, and after a few hours a few small chloroplasts. From this point two lines of development have been noted. 
In the first case, as in the typical Leptosporangiatae, a small papilla is formed and cut off from the body cell by a wall. This papilla elongates to form the first rhizoid. It contains no chloroplasts. Occasionally two such papillae are formed before the division of the prothallial cell (figs. 54, 55). Following the formation of the first rhizoid, the body cell increases in size, the oil globules disappear, and the chloroplasts increase in size and number. The second division of the spore produces a new prothallial cell containing chloroplasts.

In the second case, the first division may produce two prothallial cells similar in size, and both containing chloroplasts. The basal cell of such a group may later produce a rhizoid. From the examination of many germinating spores and young prothallia, it seems quite as common for the spore to undergo one or two divisions before the formation of a rhizoid as for the rhizoid to result from the first cell division. Numerous specimens similar to fig. $5^{2}$, but without a rhizoid, have been seen. As germination proceeds, the perinium is distended but is not cast off; it may usually be found attached to the oldest cell of mature prothallia (figs. I4, I5).

As has been stated, immediately after the rupture of the walls, light green plastids appear in the exposed portion of the cell (figs. 5I, 54). With the further growth of the spore and the formation of new cells, these chloroplasts become larger and increase rapidly in number. Throughout the life of the prothallium the chloroplasts retain a distinct yellow tinge, imparting a characteristic color to the plant. They at all times show a quick reaction to intense light, crowding close to the vertical cell walls after a few minutes of brilliant illumination. The oil globules persist for a short time only, and may not be seen after the first division of the prothallial cell.

\section{Early development of the prothallia}

As was stated above, the first division of the cell may produce two similar cells, or may cut off a small cell which develops into a rhizoid. If the first division produces a rhizoid, the second division produces two cells similar in form and containing chloroplasts. Later divisions of the distal cell may occur in either a transverse 
or longitudinal plane. In some instances consecutive transverse divisions occur until a long, protonema-like filament of many cells is formed (figs. I, 2, 3, 6I). The length of the filament may vary, but whether it be one cell or more than one cell in length, it finally produces, by longitudinal and further transverse divisions of its newer cells, a flat plate one cell in thickness. It should be noted that it is the rule for this plate to be formed by regular promiscuous divisions, without any suggestion of an apical cell or group, although exceptions may be found in unusually long filaments. Not infrequently this plate is formed immediately after the first transverse division of the spore (figs. 4, I8). In other specimens the plate formation begins after a chain of two or more cells is evident (figs. 5, 6, 8, Iо, 6I, 63). Occasionally a prothallium shows that transverse divisions have been followed or accompanied by longitudinal divisions until a strand two cells wide and as long as the simple protonemal structure mentioned above has been formed (figs. 7, II, I4). Fig. I3 shows an intermediate form where one cell of a single row has given rise to two by longitudinal division. More rarely a definite strand three cells in width is clearly shown (fig. I9). That these strands, one, two, or three cells in width, are not a part of the regular prothallial plate is indicated by the abrupt beginning of the latter (figs. 5, 6, 7, II, I4).

\section{Later growth of the prothallia}

The small prothallia increase in size by a promiscuous division of their cells in two planes. The location of growing regions and the direction of division of individual cells seem to follow no general rule. The resulting cell plates lack to a mäked degree the regularity and symmetry usually found in the prothallia of related ferns. A glance at figs. I-20 and at pl. XIII will give an idea of the many and various forms found. This continued promiscuous growth and division of the cells in the body of the prothallium is characteristic of Camptosorus rhizophyllus. In many cases prothallia of considerable size are formed by this growth alone before the formation of an apical region, as must have been true in those shown in figs. I5, I9, and 59. This type of growth continues after the appearance 


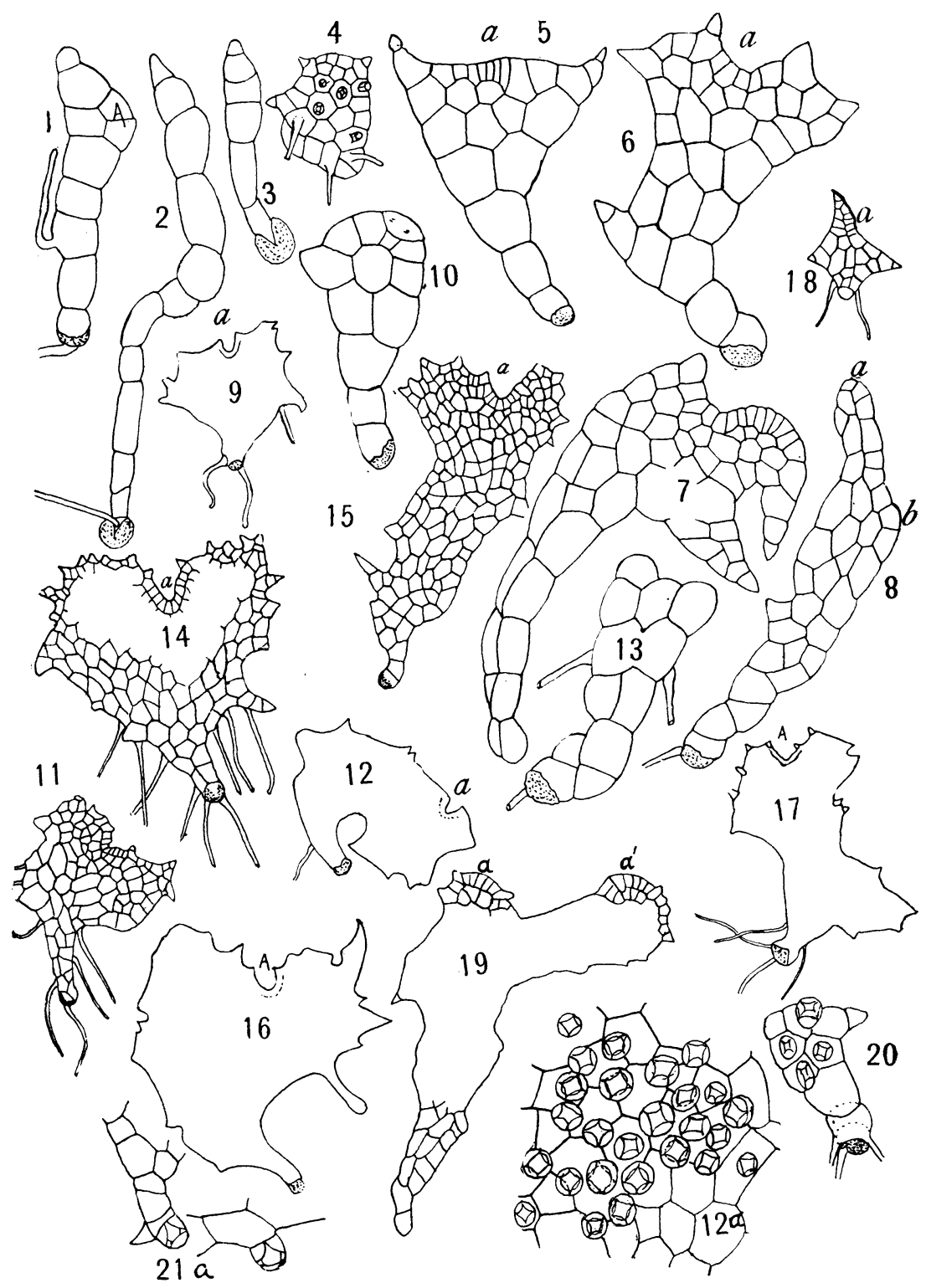

FIGS. I-2I a.-Figs. I-3, protonema-like prothallia, with possible beginning of apical growth at $A$ in fig. I, $X_{\mathrm{I} 20}$; fig. 4, small prothallium with mature antheridia, $\times 60$; figs. 5 and 14 , unusually symmetrical growth with distinct apical groups; figs. 6 , 7,8 , and ro, examples of unsymmetrical forms, $X_{\mathrm{I}_{20}}$; fig. $\mathrm{I}_{3}$, longitudinal division of one protonemal cell, $X_{I_{2}}$; fig. I 5 , prothallium with large plate of cells formed before appearance of apical group, $X_{40}$; fig. I9, prothallium with two growing points, $X_{40}$; fig. 20 , very small prothallium with mature antheridia, $X_{\mathrm{I} 20}$; fig. $2 \mathrm{I} a$, antheridia borne on marginal outgrowths, $X_{\mathrm{I}_{2} \mathrm{O}}$; fig. $\mathrm{I}_{2} a$, group of antheridia from central part of fig. I2, $X_{120}$; the other figures show various unsymmetrical arrangements of apical groups.

This content downloaded from 080.082.077.083 on February 19, 2018 18:49:22 PM 
of the apical region and even after the formation of the archegonial cushion or meristem. It is shown especially in the formation of various marginal outgrowths and in the plicate or crispate form of old prothallia. Such marginal structures, resulting from irregular

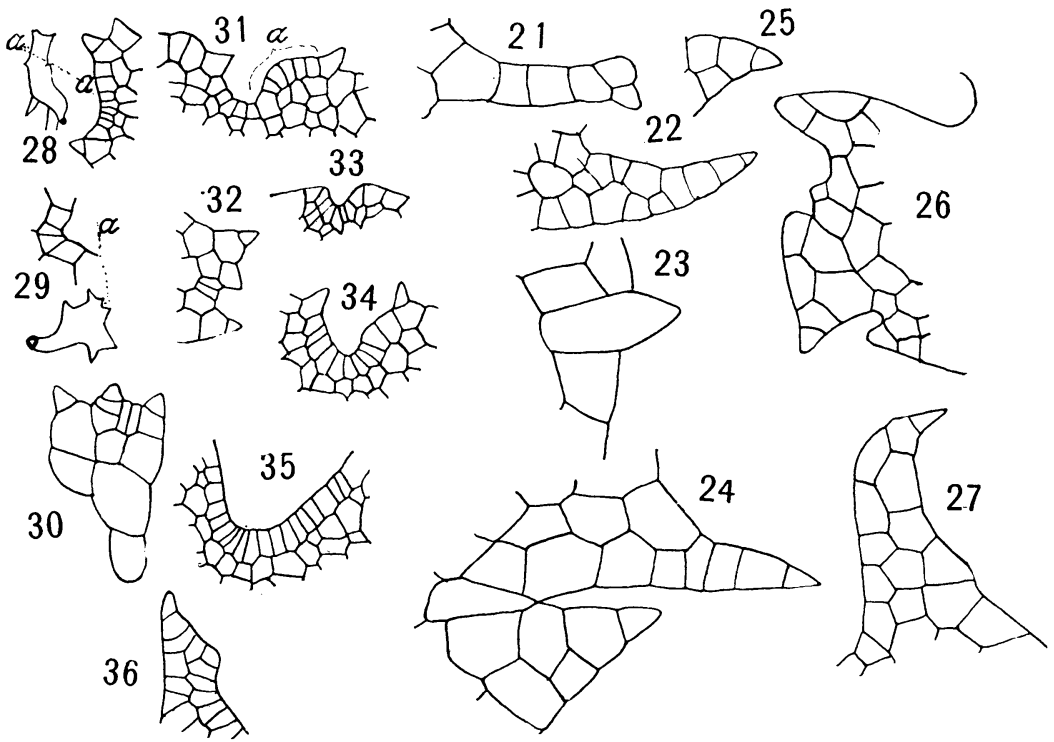

FIGS. 2I-36.-Figs. 2I-27, various marginal outgrowths; fig. 23, one-celled form growing directly from regular margin; see fig. $21 a$ for outgrowths bearing antheridia; figs. 28-36, various forms of apical cells and groups; fig. 36 is $a$ of fig. 18 more highly magnified; fig. 28 , wholly lateral apical group, and fig. 31, apical group (a) beside a sinus; all $\times_{\mathrm{I} 20}$ except small figures in figs. 28 and 29 .

cell multiplication having no connection with apical growth, are also characteristic of Camptosorus. These marginal structures may be of one or of very few cells (figs. 6, I 7, 56, 6I), or may be of many cells and approach the dignity of lobes (figs. 7, I6, 58). The form of several such lobes is shown in figs. $2 \mathrm{I}-27$.

\section{The region of apical growth}

Although the prothallia may attain considerable size and even mature gametes without the appearance of a typical $V$-form apical cell or a distinct apical group, such a growing region is quite usual and typical. The appearance of the apical cell or group is 
varied as to both time and position. In long, protonema-like structures the beginning of a specialized growth region is usually indicated by the division of a cell once or twice removed from the distal end (fig. I). In case a plate of cells has been formed as mentioned above, a group of cells anywhere about the periphery of this plate may become more active than the neighboring cells, and thus con-

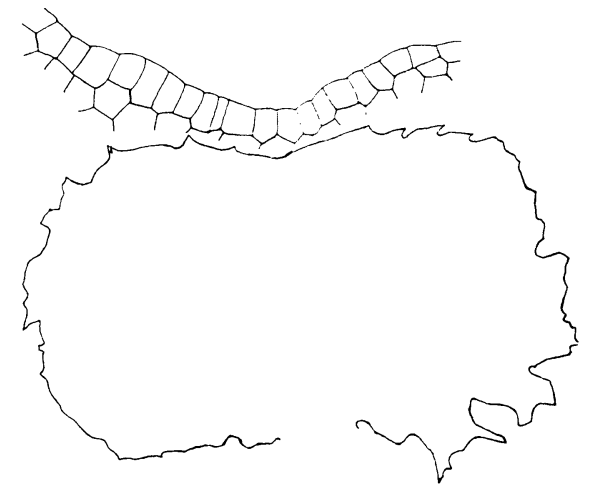

FIG. 37--Large prothallium with distal margin almost plane as a result of activity of large apical group; $\times 28$ and 160 .

stitute an apical region or group. The formation of a distinct, individual, V-shaped apical cell has not been noted, although forms like figs. 8, 29, 30, and 32 suggest such. In the plant shown in fig. 8 the growing region would probably appear between $a$ and $b$ rather than as a result of any activity of the cell at a. In many instances the apical region is quite symmetrically placed (fig. I4); but an examination of figs. 7, I2, and 17 will show the extreme variation of position, and how far from symmetrical the placing of an apical group may be. Fig. I9 shows an even more interesting case, of which a few have been found, where two such regions have been

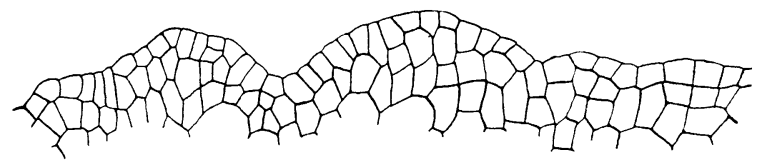

FIG. 38.-Portion of margin of large prothallium, showing almost continuous growing group; $\times 160$.

formed. The very striking irregularity in the formation of the apical group is further shown in figs. $28-36$ and in figs. 56 and 57 . Fig. 28 with the group $(a)$ entirely lateral to the evident axis of elongation, fig. 36 (an enlargement of $a$ in fig. I8), and fig. 31 with the apical group beside a sinus are worthy of notice. Figs. 33, 34, 
and 35 show about as regular or symmetrical a formation as has been found.

Another point to be noted is that as the prothallia grow older the apical group increases its activity, with the result that instead of being in a sinus of considerable depth it is pushed outward to form an almost straight margin at that place (fig. 37). Closely related to this phenomenon are the cases of proliferation now to be mentioned.

Prothallia which have grown for four or

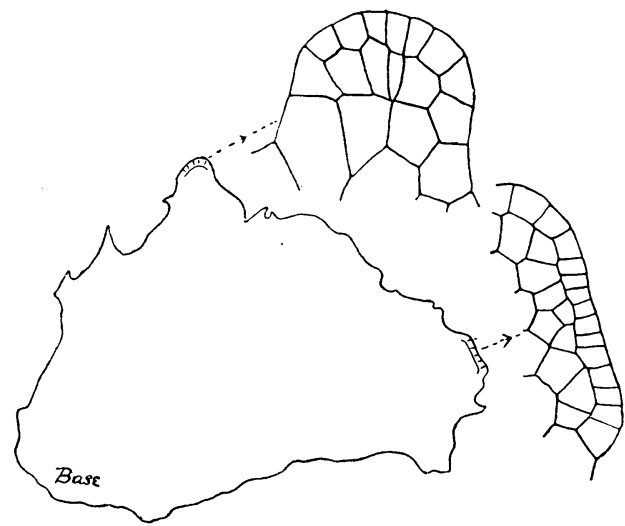

FIG. 39.-Old prothallium that has developed two special growing regions; $\times 28$ and 160 . five months, and those which have been allowed to become quite dry and recover, some-

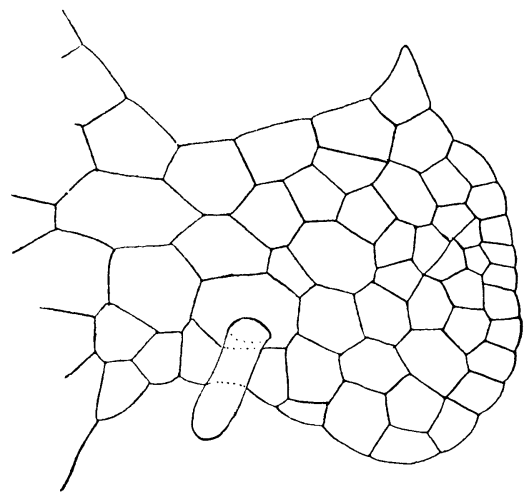

FIG. 40.-Special growing point similar to those in fig. 39 , but more fully developed and showing rhizoid; $\times \mathrm{r} 60$. times continue irregular growth at one or more points on the margin. Fig. 38 shows a part of the margin of a large prothallium with renewed growth, after desiccation for several days. Fig. 39 shows two such regions on one prothallium. Fig. 40 shows an advanced development of such a region that has produced a rhizoid and might continue growth independent of the original prothallium. On some such proliferations antheridia are formed regularly and abundantly. The presence of archegonia has not yet been noted on them. 


\section{Size of prothallia}

Prothallia bearing antheridia vary much in size at the time of maturing their first sperms. Examples of plants composed of but few cells and with mature antheridia (figs. 4, 20) are not uncommon; on the other hand, many reach a width of $\mathrm{I}-2 \mathrm{~mm}$. before producing their first antheridia. The dwarf antheridial plants never attain any great size; they are but one cell in thickness, and never produce archegonia. Fig. 4I shows the prothallium in fig. 20 and another taken at the same time from the same part of a culture and drawn to the same scale. These were just maturing their first antheridia. Antheridia are quite evenly distributed over the lower surface of the older portions of the large prothallia, and over the

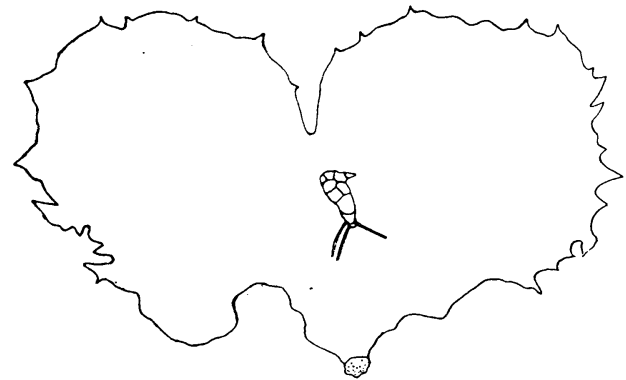

FIG. 4I. -Two prothallia of same age (as indicated by maturity of first antheridia) and from same bit of soil; $\times 28$. lower surface and margins of the dwarf forms (figs. 4, I 2a, 20). Fig. I $2 a$ shows the abundance of antheridia on the large plant in fig. $\mathrm{I} 2$. Occasionally antheridia appear on the margins and even on the marginal outgrowths of large prothallia (fig. $2 \mathrm{~s} a)$. Five months old prothallia, bearing both antheridia and archegonia, are sometimes $4 \mathrm{~mm}$. wide. They are strictly dorsiventral, although they show a marked tendency to take an upright position. The margins are distinctly crisped and plicate. After six to eight months, the marginal growth of the plants continues and the older portions die away much as in the liverworts.

The rhizoids develop regularly from the lower surface of the prothallia, and are most abundant on the central part of the older portions, that is, at the base of the plant. They are long, slender, and sparingly branched near their free ends. The photographs reproduced in $\mathrm{pl}$. XIII give a general idea of their character. The only point worthy of note is that mentioned above in connection 
with the germination of the spore, namely, that the first division of the cell may produce a second prothallial cell instead of a rhizoid.

\section{Antheridia and archegonia}

The antheridia develop in much the same general way as described by CAMPBELL ${ }^{\mathrm{I}}$ for Onoclea Struthiopteris as a type of the Leptosporangiatae. The stages in development are suggested in figs. $42^{2-46}$. The one point worthy of mention is the formation of the neck cell. This cell is cut off by a division of the initial antheridial cell in a plane parallel to the prothallial surface, and is very regularly found, although sometimes the more orthodox development shown in fig. 44 is evident.

The archegonial meristem is but little in evidence, being of small area and not conspicuous. It develops on prothallia soon after the appearance of the antheridia, and is found only on such plants as have a well formed apical group. Archegonia are found on plants $\mathrm{I} .5 \mathrm{~mm}$. or more in width. Their development is in every way typical of the Leptosporangiatae, but only a few (4-8) are found on a prothallium.

\section{Summary}

The spores of Camptosorus rhizophyllus germinate very irregularly in point of time.

Prothallia bearing antheridia only and those bearing both antheridia and archegonia are produced.

Both antheridial and archegonial prothallia show a wide variation in size and form, the result of a promiscuous cell division and growth.

The formation of a typical V-shaped apical cell is rarely found, if at all, and the apical group is usually unsymmetrically placed.

Old prothallia, bearing both antheridia and archegonia, may develop several marginal growing regions, and may even produce proliferations capable of independent growth.

The archegonia follow the typical Leptosporangiatae in their

I Mosses and ferns, 1905, p. 315. 
development. The antheridia usually form a neck cell before the regular antheridial divisions.

INDIANA UNIVERSITY

Bloomington, Ind.

\section{EXPLANATION OF PLATES XII AND XIII}

(Figs. I-4I in text)

PLATE XII

All figures $\times 660$

FIGS. 42-46.-Stages in development of antheridia; fig. 44 shows orthodox form sometimes found, the others show more usual form with a neck cell.

FIG. 47.-Fresh, mature spore.

FIG. 48.-Spore with cell showing through ruptured coats.

FIG. 49.-Spore with rhizoid showing first.

FIGS. 50, 5I.-Rhizoids issuing from the cell exposed by the rupture of the coats: og, oil globules.

FIGS. 52, 53.-First and second divisions of the prothallial cell.

Figs. 54, 55.-Two rhizoids formed by the undivided spore.

\section{PLATE XIII}

All figures $\times 75$

FIGS. 56-64.-Photographs of living prothallia which, with many others, were taken at one time from one small bit of soil; only enough are shown to indicate the variation in form and growth. 


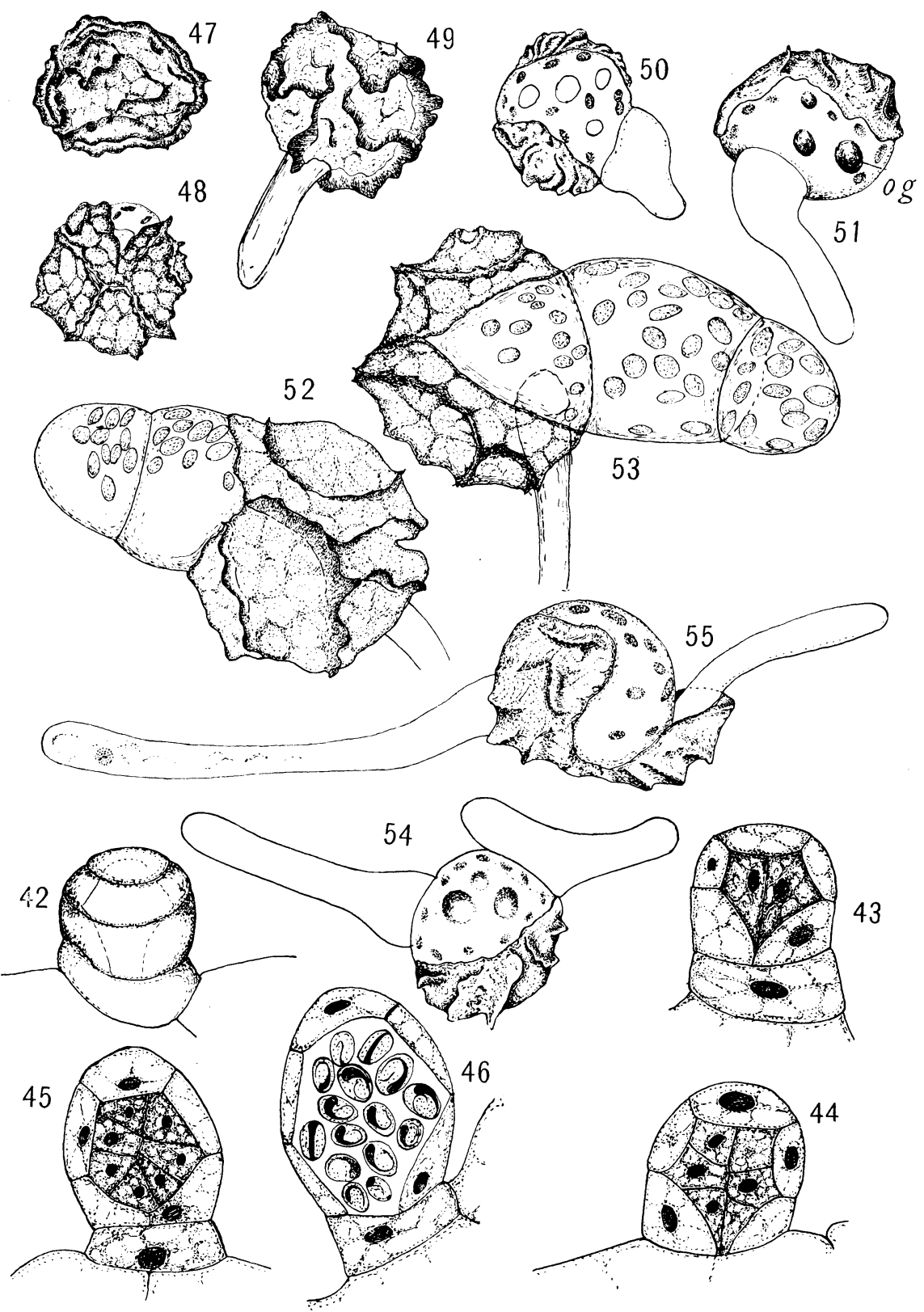

PICKET'T on CAMPTOSORUS 


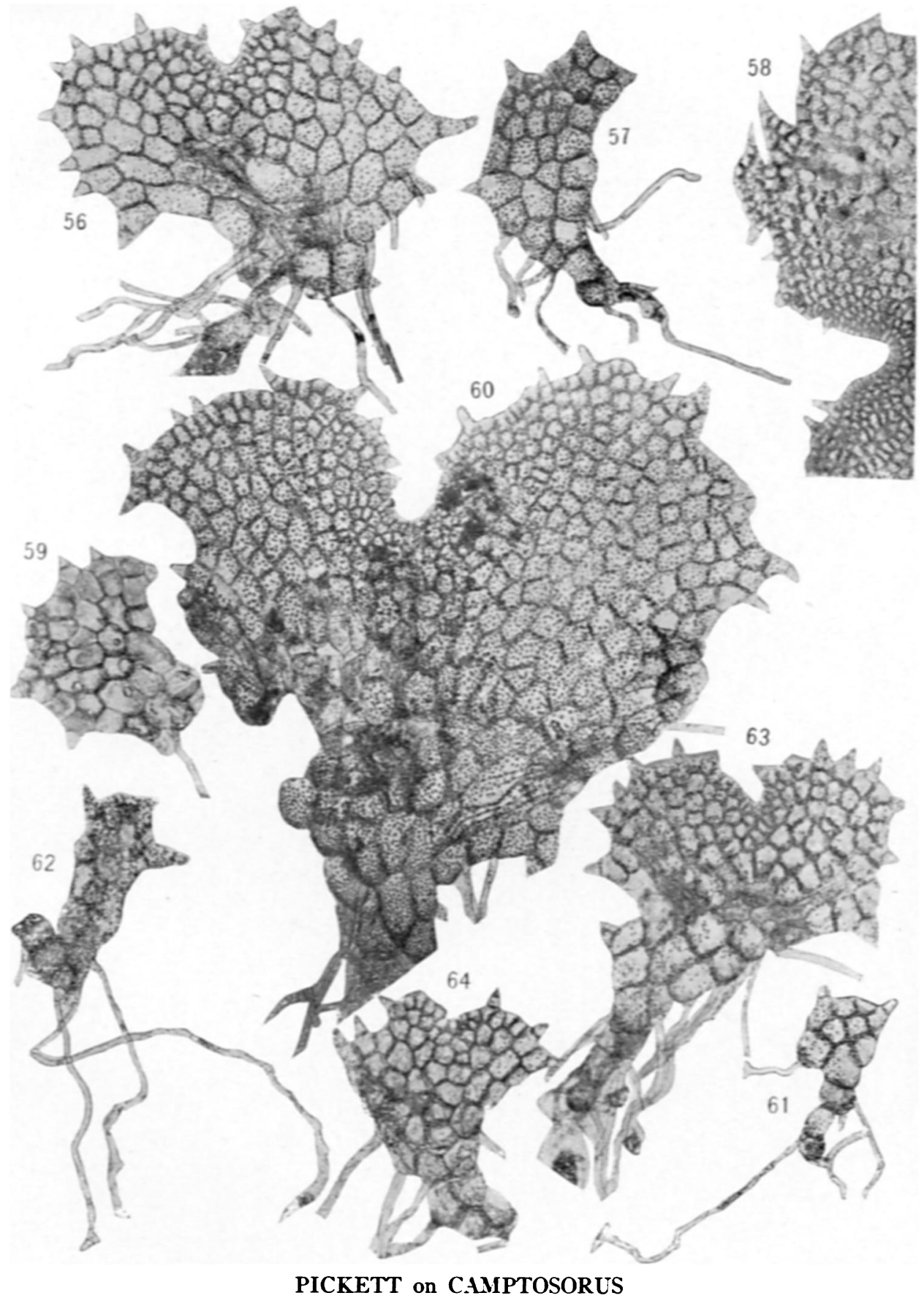

This content downloaded from 080.082.077.083 on February 19, 2018 18:49:22 PM All use subject to University of Chicago Press Terms and Conditions (http://www.journals.uchicago.edu/t-and-c). 